\title{
Prognostic indicators in a range of astrocytic tumours: an immunohistochemical study with $\mathrm{Ki}-67$ and p53 antibodies
} David W Ellison, Philip V Steart, Adrian C Bateman, Ruth M Pickering, James D Palmer,
Roy O Weller

Abstract

The treatment and prognosis of patients with cerebral astrocytic tumours are currently guided by histopathological classification. This study evaluates immunohistochemistry using Ki-67, an antibody to a nuclear protein expressed in proliferating cells, and DO-7, an antibody to the product of the tumour suppressor gene p53, as prognostic indicators for these tumours. Immunohistochemistry with Ki-67 has been correlated with the behaviour of many different tumours, but its value as a prognostic indicator in astrocytic tumours is diminished by the conflicting results of previous studies. Immunohistochemistry with antibodies to the p53 protein has been used as a prognostic indicator in melanomas and some carcinomas, but the relation between prognosis and accumulation of this protein in astrocytic tumours has not been clarified. We have tested the hypothesis that survival is correlated with $\mathrm{Ki}-67$ immunolabelling indices (LIs) and patterns of p53 immunolabelling in the cerebral astrocytic tumours of a large cohort of patients $(n=123)$ for whom clinical indices were well documented. Astrocytic tumours were divided into three histological types: fibrillary astrocytoma ( $n=$ 24), anaplastic astrocytoma $(n=31)$, and glioblastoma $(n=68)$. Histological type and patient age were independent predictors of survival. Median Ki-67 LIs differed significantly $(P<0.0001)$ between the types of astrocytic tumour, and tumours with a Ki-67 LI $<2 \%$ had a significantly $(P<0.0001)$ better prognosis. Ki-67 LI as a continuous variable carried a significant (P=0.0043) unadjusted hazard to survival which was lost when adjusted for other variables, notably histological type. By contrast, no relation was found between survival and three categories of p53 labelling (p53-negative, p53 LI $<40 \%$, and p53 LI $>60 \%$ ). The results indicate that, whereas Ki-67 immunohistochemistry predicts survival in patients with astrocytic tumours, conventional histological appraisal remains the best guide to prognosis, and immunohistochemistry for p53 has no value in the assessment of these tumours.
$(\Im$ Neurol Neurosurg Psychiatry 1995;59:413-419)

Keywords: astrocytoma; prognosis; p53 protein; $\mathrm{Ki}-67$ antibody

Astrocytic tumours are primary CNS tumours that have three principal histological types: fibrillary astrocytoma, anaplastic astrocytoma, and glioblastoma. ${ }^{2}$ A progressively poorer prognosis is associated with the increasingly undifferentiated histological appearance of the tumours across this range. Fibrillary astrocytomas occur predominantly in adults aged 20-40 years. ${ }^{3}$ Because of their infiltrative nature, resection is often not possible; however, the slow growth of these tumours may permit survival for several years after surgery, and before further neurological symptoms herald a recurrence. About $70 \%$ of fibrillary astrocytomas evolve into anaplastic astrocytomas over a period of 10-15 years, at which stage the tumours show cellular atypia and an increased proliferation rate. ${ }^{3}$ Whereas about $30 \%$ of diffuse cerebral astrocytomas eventually evolve into glioblastomas, most glioblastomas arise de novo in patients aged $40-70$ years. ${ }^{3}$ Few patients with anaplastic astrocytomas and glioblastomas survive two years beyond diagnosis. ${ }^{4}$

Although distinction between astrocytomas with a good prognosis and astrocytomas with a poor prognosis can often be made on histological features; for some tumours histological differentiation is not clear, especially when only small fragments of tissue from stereotactically guided needle biopsies are available. It is for this reason that more objective criteria for predicting the prognosis of brain tumours are required.

In recent years, the value of antibodies to proteins expressed in proliferating cells, such as $\mathrm{Ki}-67$ and PC10, has been investigated in astrocytic tumours. ${ }^{5-8}$ The $\mathrm{Ki}-67$ antibody recognises a non-histone, nuclear protein that is expressed throughout all phases of the cell cycle except $G_{0}$ and the early part of $G_{1} \cdot{ }^{9}$ Several antibodies have now been raised against this antigen and used successfully to measure the growth fraction of tumours; and the $\mathrm{Ki}-67$ labelling index (LI) correlates well with the behaviour of many different malignant tumours. ${ }^{10}$ Immunolabelling with $\mathrm{Ki}-67$ initially required frozen tissue sections, but the development of new antibodies and the 
advent of microwave based antigen retrieval techniques have produced good results with formalin fixed, paraffin embedded tissues. ${ }^{11}$

There is a strong relation between histological type of astrocytic tumour and $\mathrm{Ki}-67 \mathrm{LIs},{ }^{56}$ and a few studies have related $\mathrm{Ki}-67 \mathrm{LIs}$ to survival. ${ }^{81213}$ A clear relation between $\mathrm{Ki}-67$ LI and survival was either found, ${ }^{12}$ or not found. ${ }^{813}$ The analysis is devalued, however, in one of these studies by a small number of patients, and in another by a small number of low grade astrocytomas.

Studies on prognostic indicators in malignant melanomas and carcinomas of the breast, lung, and prostate gland have shown that immunohistochemistry using antibodies to the p53 protein is of value in predicting the behaviour of these tumours. ${ }^{14-17}$ For example, a considerably worse prognosis is found for patients with breast carcinomas that express the p53 protein in most tumour cells. ${ }^{14}$ The p53 tumour suppressor gene encodes a nuclear phosphoprotein of 393 amino acids which functions as a transcription factor. ${ }^{18}{ }^{19}$ It is involved in the initiation of DNA repair, and to optimise this, p53 halts the cell cycle in $G_{1}$ before DNA replication occurs in the $S$ phase. ${ }^{2021}$ Cells beyond repair may be stimulated by $\mathrm{p} 53$ to undergo apoptosis. ${ }^{22}$ Mutations of the p53 gene are currently the most frequent genetic abnormalities found in human tumours, ${ }^{23}$ and produce inactive proteins that fail to bind DNA. ${ }^{24}$ This permits the replication of damaged DNA which may then act to promote the mutational activation of proto-oncogenes. Further mechanisms that prevent the sequence specific binding of wild type p53 to DNA include the formation of inactive hetero-oligomers between some mutant and wild type proteins (dominant negative action), and the overexpression of genes, such as $m d m-2$, the products of which bind the p53 protein. ${ }^{25}$ Mutations of p53 have been found in about one third of fibrillary astrocytomas, anaplastic astrocytomas, and glioblastomas. ${ }^{27}$ Overexpression of $m d m-2$ in astrocytomas is, however, unusual..$^{28} 29$

In normal cells, the p53 protein is present in minute quantities that are undetectable by immunohistochemistry. Mutation of the p53 gene or stabilisation of the wild type protein by various mechanisms increases the half life of the protein and produces immunohistochemically detectable levels. ${ }^{30}$ Nuclear accumulation of the p53 protein has now been found in many tumours, and various patterns of immunolabelling are seen. A few positively labelled cells may be scattered through histological sections of tumour, or nearly all cells may be labelled. About one third of fibrillary astrocytomas contain scattered p53 labelled cells, whereas nearly two thirds of anaplastic astrocytomas and glioblastomas contain p53 positive cells. ${ }^{2731} \mathrm{~A}$ positive correlation between accumulation of $\mathrm{p} 53$ and indices of cell proliferation has been proposed for astrocytic tumours, ${ }^{32}{ }^{33}$ but the prognostic significance of patterns of p53 accumulation is unknown.

The aim of this study was to assess the value of immunohistochemistry with $\mathrm{Ki}-67$ and p53 antibodies in the prognosis of astrocytic tumours.

\section{Materials and methods}

Cerebral astrocytic tumours from 123 adult patients $(63 \%$ men $)$ were selected from archival material in the department of neuropathology in Southampton. The tumours were divided histologically according to the World Health Organisation 1993 classification $^{1}$ into fibrillary astrocytoma $(n=24)$, anaplastic astrocytoma $(n=31)$, and glioblastoma $(n=68)$. No pilocytic astrocytomas were included in this series. Most of the patients $(n=103)$ had been enrolled with the European Organisation for Research and Treatment of Cancer (EORTC) into randomised, prospective studies of various adjunctive treatments to radiotherapy. None of the studies had shown a significant improvement in survival for any of the new treatments. Comprehensive clinical details and outcome data were available for patients entered into the EORTC trials. Information on the other patients was derived from the clinical notes of the Wessex Neurological Centre. The percentage of tumours in the frontal lobe, temporal lobe, and parieto-occipital region respectively were: $58 \%, 25 \%$, and $17 \%$ for fibrillary astrocytomas; $35 \%, 23 \%$, and $42 \%$ for anaplastic astrocytomas; and $44 \%, 26 \%$, and $30 \%$ for glioblastomas. After craniotomy at which the biopsies in this study were taken, 57 patients had been treated with radiotherapy alone, 30 patients had received radiotherapy and chemotherapy, ${ }^{34} 14$ patients had received a radiosensitiser before radiotherapy, ${ }^{35}$ eight patients, mostly with fibrillary astrocytomas, had received no additional treatment after surgery, and precise details of treatment were unavailable for 14 patients.

\section{IMMUNOHISTOCHEMISTRY}

Near adjacent sections $(5 \mu \mathrm{m})$ of paraffin embedded tissue were first floated on to slides previously coated with 3-aminopropyltriethoxysilane, and dried at $37^{\circ} \mathrm{C}$ overnight. They were then dewaxed, rehydrated to $70 \%$ methanol, and treated with freshly prepared $1 \% \mathrm{H}_{2} \mathrm{O}_{2}$ in methanol to block endogenous peroxidase activity. This was followed by an antigen retrieval technique to enhance immunolabelling. The slides were placed in plastic Coplin jars containing $0.01 \mathrm{M}$ citrate buffer (pH 6.0), and then boiled in a microwave oven (Panasonic 6400) for two cycles (DO-7) or four cycles (Ki-67) of five minutes on the medium power setting. The buffer boils after about 150 seconds and lost fluid is replaced between cycles. The jars were removed from the oven and allowed to cool for 15 minutes before immunolabelling.

The DO-7 monoclonal antibody to p53 (DAKO) which recognises both wild type and mutant proteins and a polyclonal $\mathrm{Ki}-67$ antibody (DAKO) were applied to the treated sections having been diluted 1:100 and 1:50 respectively in Tris buffered normal saline 
(TBS). Biotinylated antimouse antibody (Amersham) diluted 1:200 in TBS was used in the second stage with DO-7. Biotinylated antirabbit antibody (DAKO) diluted 1:400 in TBS was used in the second stage with $\mathrm{Ki}-67$. Streptavidin-biotin horseradish peroxidase complex (DAKO) diluted 1:200 in TBS was used in the third stage. Both second and third stages were performed at room temperature for 30 minutes. Antigen-antibody complexes were visualised with a standard diaminobenzadine technique. Control sections were incubated without primary antibody, and all sections were counterstained with haematoxylin.

\section{ASSESSMENT OF LABELLING INDICES}

Sections for immunohistochemistry were cut from selected tissue blocks containing tumour with the characteristic histological features of each type of astrocytoma. In particular, the sections from anaplastic astrocytomas showed tumour cells with a high nuclear: cytoplasmic ratio, nuclear hyperchromasia, and mitoses, and not just a few foci of cellular atypia among well differentiated astrocytic cells with a low nuclear: cytoplasmic ratio. LIs for glioblastomas were calculated from areas of sections that were free from necrosis or capillary endothelial proliferation. The infiltrative edge of the tumour where neoplastic cells surround normal neurons and glia was also avoided. Where an uneven distribution of immunohistochemical labelling was evident, fields from the area of maximal labelling were chosen for counting; otherwise, fields were randomly chosen with the provisos stated. An eyepiece grid was used for counting which was undertaken at a magnification of $\times 320$, and the denominator for each labelling index was at least 1000 tumour cells.

\section{STATISTICS}

Median levels of $\mathrm{Ki}-67 \mathrm{LI}$ in the three histological groups and in the three p53 categories were compared by Kruskal-Wallis test. Survival times were calculated as time from surgery to death, or time to last follow up appointment in the case of survivors. Kaplan-Meier curves were produced to compare duration of survival between groups. Prognostic factors were entered into a Cox proportional hazards model: each term being tested on its own and in the presence of others. $\mathrm{Ki}-67 \mathrm{LI}$ and p53 LI were considered as continuous variables, and categorised into three levels. Only the categorical version was considered in the adjusted Cox model. Likelihood ratio tests were undertaken for each variable, and relative hazards with corresponding $95 \%$ confidence intervals were produced. The analysis was performed in STATA. ${ }^{36}$

\section{Results}

For each type of astrocytic tumour, the average age of patients at operation was: fibrillary astrocytoma, 35 (range 23-54) years; anaplastic astrocytoma, 41 (16-67) years; and glioblastoma, $51(30-66)$ years. The associated median survival times for patients who had died by the time of the study $(n=100)$ were: fibrillary astrocytoma 1026 days, anaplastic astrocytoma 377 days, and glioblastoma 321 days.

Distinct labelling of nuclei in tumour cells occurred with the $\mathrm{Ki}-67$ antibody (fig 1 ) in all astrocytic tumours. Whereas only a few $\mathrm{Ki}-67$ positive cells were found in entire sections from some fibrillary astrocytomas, one glioblastoma had a $\mathrm{Ki}-67 \mathrm{LI}$ of $41 \cdot 5 \%$. Table 1 gives the percentage of tumours with $\mathrm{Ki}-67$ LIs above and below $2 \%$ for the three types of astrocytic tumour. Nearly all (96\%) of the fibrillary astrocytomas had $\mathrm{Ki}-67 \mathrm{LIs}$ below $2 \%$, whereas $83 \%$ of glioblastomas had Ki-67 LIs above $2 \%$. Median Ki-67 LI was significantly different $(P<0.0001)$ between the three types of astrocytic tumour (table 2).

Nuclear labelling with the DO-7 antibody to p53 (fig 2) was found in tumours from all three histological types. The intensity of the immunolabelling and the distribution of positively labelled cells within a section could be

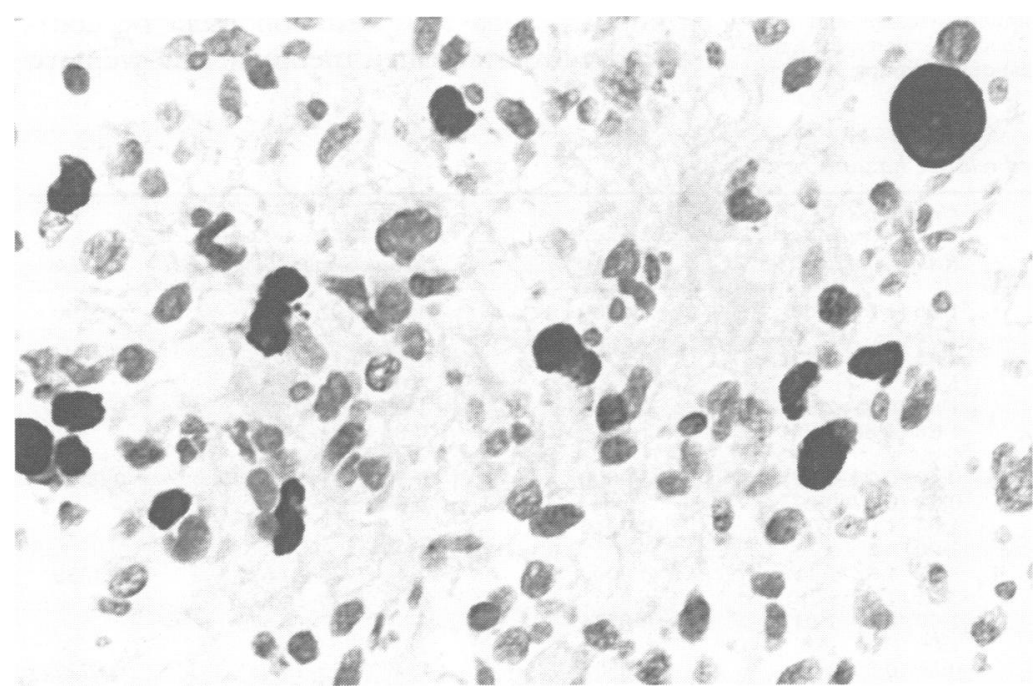

Figure 1 Positive immunolabelling of nuclei in a glioblastoma with the Ki-67 antibody. Other nuclei are counterstained with haematoxylin (originally $\times 300$ ).
Table 1 Percentage of tumours in two categories of Ki-67 immunolabelling and three categories of $p 53$ immunolabelling

\begin{tabular}{llll}
\hline & $\begin{array}{l}\text { Fibrillary } \\
\text { astrocytoma } \\
(n=24)\end{array}$ & $\begin{array}{l}\text { Anaplastic } \\
\text { astrocytoma } \\
(n=31)\end{array}$ & $\begin{array}{l}\text { Glioblastoma } \\
\text { multiforme } \\
(n=68)\end{array}$ \\
\hline Ki-67 LI $<2 \%$ & 96 & 45 & 17 \\
Ki-67 LI > 2\% & 4 & 55 & 83 \\
p53 negative & 34 & 26 & 39 \\
p53 LI < 40\% & 58 & 42 & 40 \\
p53 LI > 60\% & 8 & 32 & 21 \\
\hline
\end{tabular}

Table 2 Ki-67 LI by histological subtype

\begin{tabular}{lrlll}
\hline & Total & Median (IQR) P value \\
\hline All cases & \multicolumn{1}{l}{ 123 } & $3.39(6.88)$ & \\
Fibrillary astrocytoma & 24 & $0.38(0.92)$ & \\
Anaplastic astrocytoma & 31 & $2.48(3.87)$ & $0.0000^{\star}$ \\
Glioblastoma multiforme & 68 & $5.71(6.63)$ & \\
\hline
\end{tabular}

Ki-67 LI was not normally distributed. Median and interquartile range (IOR) have therefore been calculated for a nonparametric analysis ( ${ }^{\star}$ Kruskal-Wallis) of the groups. 


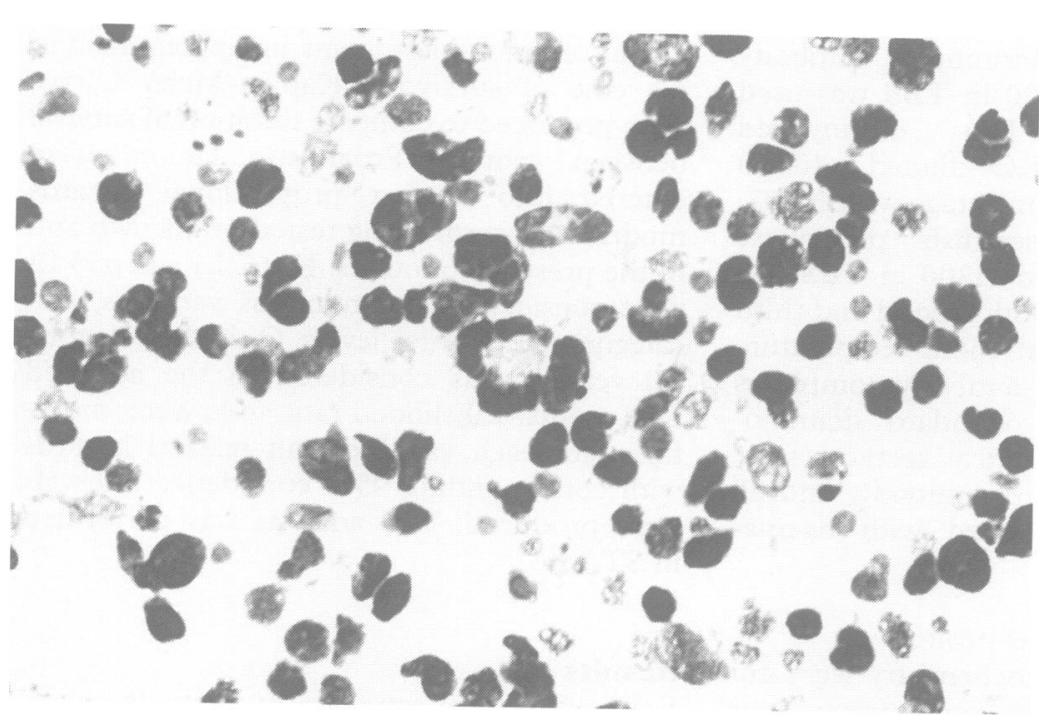

Figure 2 Positive immunolabelling of nuclei in a glioblastoma with the DO-7 antibody. Other nuclei are counterstained with haematoxylin (originally $\times 300$ ).

variable; however, most $\mathrm{p} 53$ positive tumours contained an even distribution of labelled cells from which a labelling index could readily be calculated. The range of p53 LIs was large $(0 \%-98 \%)$ and the frequency distribution of LIs was U shaped. Thus many p53-positive tumours were located at each end of the p53 LI range, but none had a value between $40 \%$ and $60 \%$. Therefore, all p53 positive tumours could be divided into two categories: p53 LI $<40 \%$ and p53 LI $>60 \%$. Table 1 shows the percentage of tumours in three categories of p53 immunolabelling for the three types of astrocytic tumour.

The median $\mathrm{Ki}-67 \mathrm{LIs}$ of three categories of p53 immunolabelling were compared (table 3 ), and the group of astrocytic tumours with a

Table 3 Ki-67 LI by p53 category

\begin{tabular}{lrll}
\hline & Total & Median (IQR) & P value \\
\hline All cases & 123 & $3.39(6 \cdot 88)$ & \\
p53 negative & 43 & $3.30(4 \cdot 46)$ & \\
p53 LI $<40 \%$ & 54 & $3.05(5.04)$ & $0.0377^{\star}$ \\
p53 LI $>60 \%$ & 26 & $7.05(11.6)$ & \\
\hline
\end{tabular}

Ki-67 LI was not normally distributed. Median and interquartile range (IQR) have therefore been calculated for a nonparametric analysis ( ${ }^{\star}$ Kruskal-Wallis) of the groups.
partile range p53 LI > 60\% was found to have a significantly $(P=0.0377)$ greater Ki-67 LI. The combination of the relation between $\mathrm{Ki}-67 \mathrm{LI}$ and type of astrocytic tumour, and the different proportions of each type of astrocytic tumour in the p53 categories might confound this analysis. When glioblastomas were analysed alone, however, the median $\mathrm{Ki}-67 \mathrm{LI}$ of the p53 LI > 60\% group (9.28) was also significantly $(P=0.03)$ greater than the median Ki$67 \mathrm{LIs}$ for the p53 LI $<40 \%$ group $(6.05)$ and the p53 negative group (4.4).

Table 4 shows the relative hazards to survival for several variables. There was no significant relation $(P=0.87)$ between treatment regimen and survival (not shown). Neither sex nor tumour site were prognostic indicators: however, age was a significant $(P=$ 0.01 ) and independent hazard to survival. $\mathrm{Ki}-$ $67 \mathrm{LI}$ as a continuous variable carried a significant $(P=0.0043)$ unadjusted hazard to survival, the categories with $\mathrm{Ki}-67 \mathrm{LI}>2 \%$ showing relative hazards above three. This effect was reduced and insignificant when adjusted for other variables, due to the close relation between $\mathrm{Ki}-67 \mathrm{LI}$ and histological type of astrocytic tumour. The most important prognostic indicator was type of astrocytic tumour. Anaplastic transformation of an astrocytoma or a diagnosis of glioblastoma significantly $(P<0.0001)$ shortened survival, and this effect was independent of other variables.

The substantial difference in survival associated with the three types of astrocytic tumour and a $\mathrm{Ki}-67 \mathrm{LI}$ above and below $2 \%$ is seen in Kaplan-Meier survival curves (figs 3 and 4 respectively). Survival curves for patients with tumours divided according to category of p53 labelling are very similar (fig 5). This pattern was maintained when the three categories of p53 labelling were compared for each type of astrocytic tumour (not shown).

\section{Discussion}

This study has examined the prognostic value of immunohistochemistry with $\mathrm{Ki}-67$ and p53 antibodies in a large series of astrocytic tumours. Such an evaluation must be compared with established methods, and we have

Table 4 Unadjusted and adjusted relative hazards to survival

\begin{tabular}{|c|c|c|c|c|c|}
\hline \multirow{2}{*}{$\begin{array}{l}\text { Variable } \\
(n=123)\end{array}$} & \multirow[b]{2}{*}{ Category } & \multicolumn{2}{|l|}{ Unadjusted } & \multicolumn{2}{|l|}{ Adjusted } \\
\hline & & Relative hazard $(95 \%$ CI) & P value & Relative hazard ( $95 \%$ CI) & Pvalue \\
\hline $\begin{array}{l}\text { Age } \\
\text { Sex }\end{array}$ & $\begin{array}{l}\mathrm{RH} / \mathrm{UI}^{\star} \\
\mathrm{Men}\end{array}$ & $\begin{array}{l}1.06(1.04-1.08) \\
1.00\end{array}$ & 0.0000 & $\begin{array}{l}1.03(1.01-1.06) \\
1.00\end{array}$ & 0.0100 \\
\hline \multirow[t]{2}{*}{ Tumour site } & Women & $\begin{array}{l}0.94(0.62-1.42) \\
1.00\end{array}$ & $0 \cdot 7719$ & $\begin{array}{l}1 \cdot 13(0 \cdot 73-1 \cdot 76) \\
1.00\end{array}$ & 0.5595 \\
\hline & $\begin{array}{l}\text { Temporal } \\
\text { Occipitoparietal } \\
\text { Glioblastoma }\end{array}$ & $\begin{array}{l}1.42(0.87-2 \cdot 32) \\
1.28(0.80-2 \cdot 06) \\
1.00\end{array}$ & $0 \cdot 3257$ & $\begin{array}{l}1.25(0.74-2.12) \\
0.85(0.51-1.42) \\
1.00\end{array}$ & $0 \cdot 3972$ \\
\hline Histology & $\begin{array}{l}\text { Anaplastic astrocytoma } \\
\text { Fibrillary astrocytoma }\end{array}$ & $\begin{array}{l}0.40(0.24-0.67) \\
0.14(0.07-0.27)\end{array}$ & 0.0000 & $\begin{array}{l}0.59(0.31-1.15) \\
0.22(0.09-0.56)\end{array}$ & 0.0037 \\
\hline \multirow[t]{2}{*}{$\begin{array}{l}\text { Ki-67 LI } \\
\text { Ki-67 group }\end{array}$} & $\begin{array}{l}\mathrm{RH} / \mathrm{UI}^{\star} \\
\mathrm{Ki}-67 \mathrm{LI}\end{array}$ & $\begin{array}{l}1.04(1.01-1.06) \\
1.00\end{array}$ & 0.0043 & 1.00 & \\
\hline & $\begin{array}{l}\mathrm{Ki}-67 \mathrm{LI} 2-5 \% \\
\mathrm{Ki}-67 \mathrm{LI}>5 \%\end{array}$ & $\begin{array}{l}3.13(1.81-5 \cdot 44) \\
3 \cdot 21(1.95-5 \cdot 28)\end{array}$ & 0.0000 & $\begin{array}{l}1.43(0.76-2.66) \\
1.04(0.55-1.95)\end{array}$ & 0.4038 \\
\hline \multirow[t]{2}{*}{$\begin{array}{l}\text { p53 LI } \\
\text { p53 group }\end{array}$} & $\begin{array}{l}\text { RH/UI* } \\
\text { p53-negative }\end{array}$ & $\begin{array}{l}1.00(0.99-1.01) \\
1.00\end{array}$ & $0 \cdot 8576$ & $\overline{1.00}$ & \\
\hline & $\begin{array}{l}\text { p53 } \mathrm{LI}<40 \% \\
\text { p53 } \mathrm{LI}>60 \%\end{array}$ & $\begin{array}{l}0.86(0.55-1.34) \\
1.07(0.62-1.85)\end{array}$ & 0.6502 & $\begin{array}{l}0.90(0.55-1.47) \\
1.02(0.58-1.82)\end{array}$ & 0.8722 \\
\hline
\end{tabular}




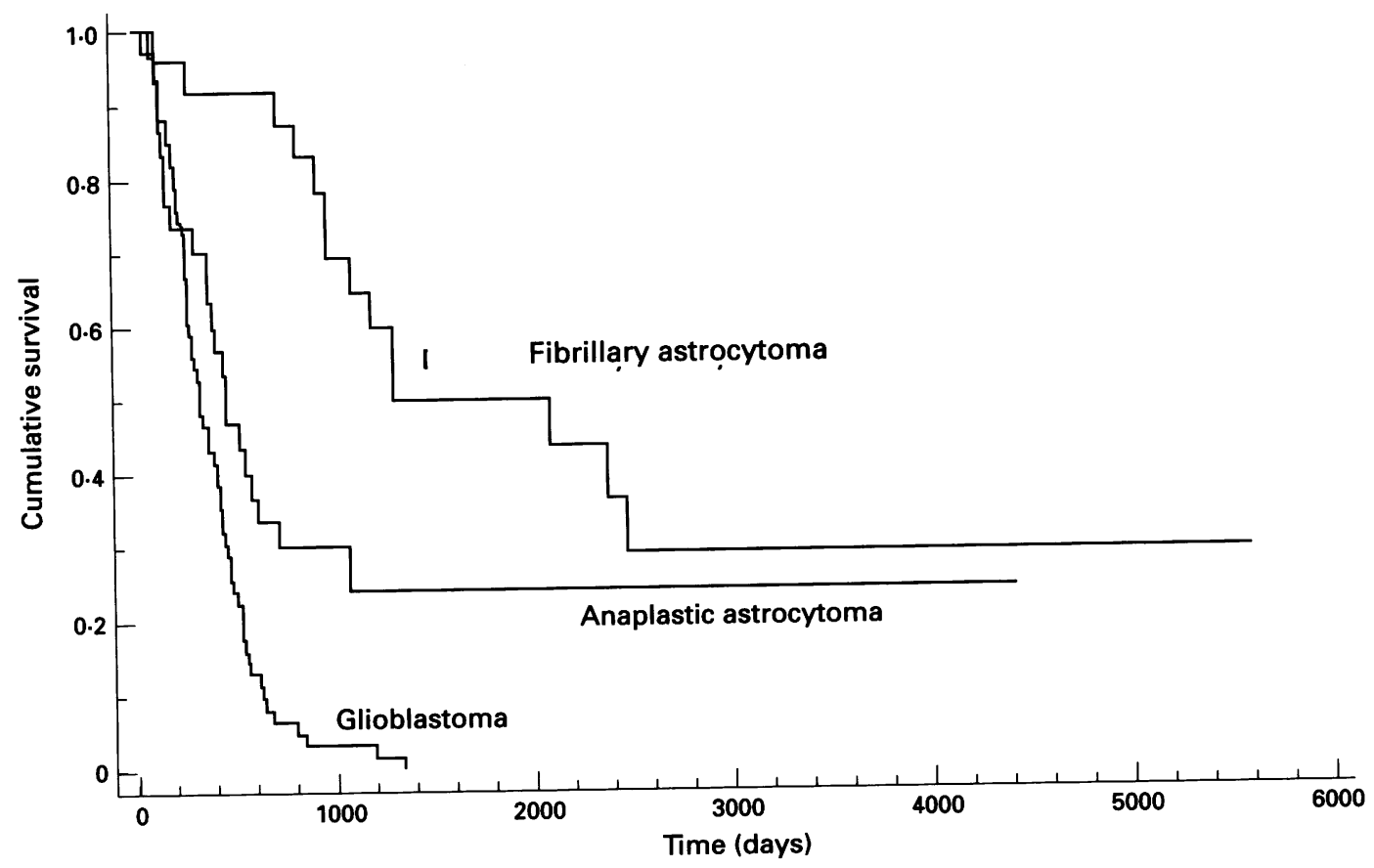

Figure 3 Survival curves for three types of astrocytic tumour.

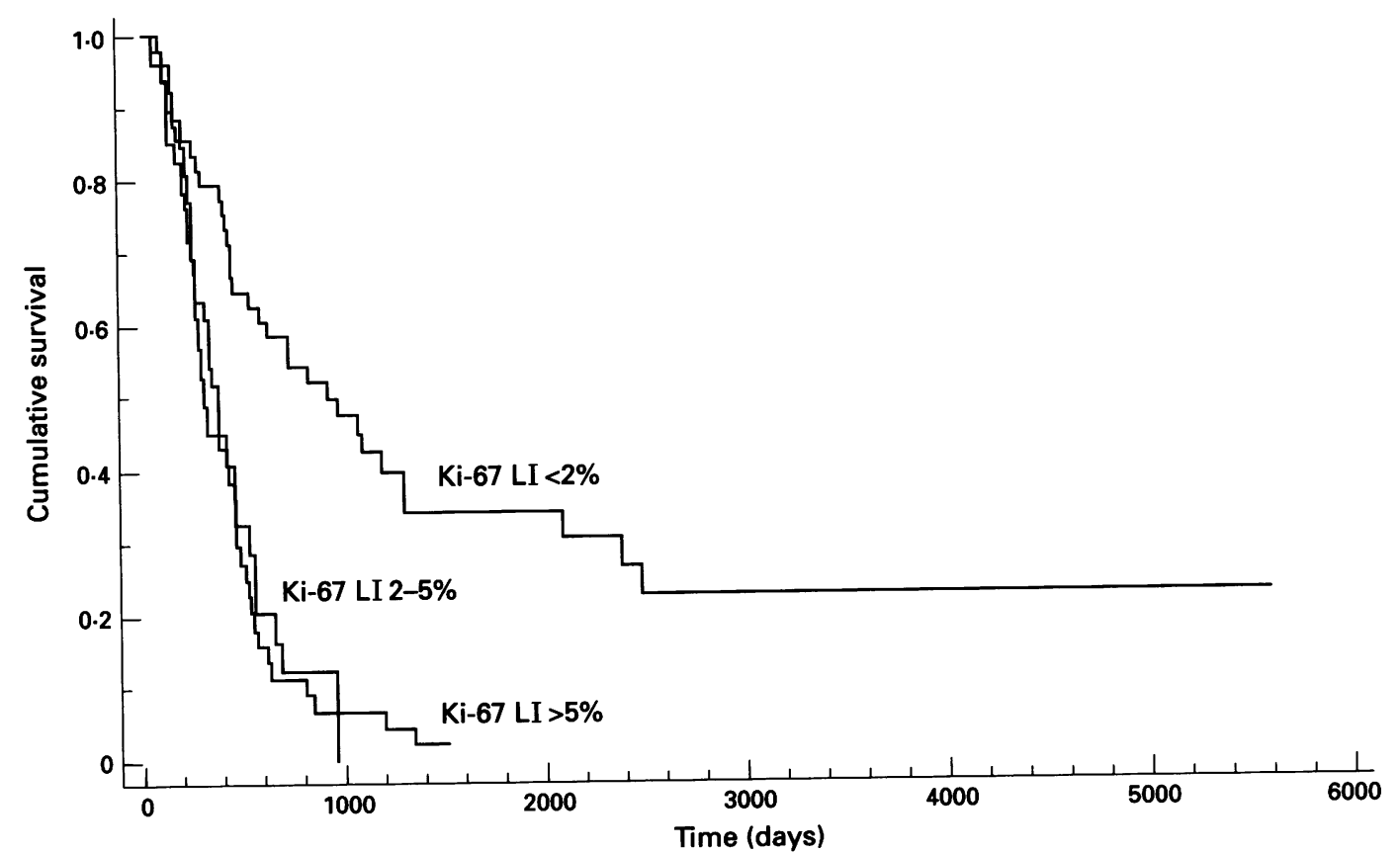

Figure 4 Survival curves for three categories of Ki-67 immunolabelling.

shown that conventional histological appraisal of these tumours remains the best guide to prognosis. Clinical variables in our series of patients, such as sex, site of tumour, and therapeutic regimen, were not important for prognosis. These results and other characteristics of patients in our study, such as the preponderence of men and mean age for each tumour type, match the findings of previous studies. ${ }^{2437-39}$

An increasing median $\mathrm{Ki}-67 \mathrm{LI}$ was found across the range of astrocytic tumours from fibrillary astrocytoma to glioblastoma. The median $\mathrm{Ki}-67 \mathrm{LIs}$ for the tumour types in the present series are very close to those in separate studies undertaken by us on frozen sections of astrocytic tumours. ${ }^{58}$ Other studies have shown an increasing mean $\mathrm{Ki}-67 \mathrm{LI}$ across the same range of cerebral astrocytomas, and one of these studies has also shown a negative correlation between $\mathrm{Ki}-67$ LI and survival. 6121340 In the present study, we have shown a difference in survival between patients with astrocytic tumours showing a $\mathrm{Ki}-67 \mathrm{LI}$ of less than $2 \%$, and patients with astrocytic tumours showing a $\mathrm{Ki}-67 \mathrm{LI}$ of more than $2 \%$, the significance of which was lost after adjusting for other variables. That this reflects the close association between histological features accompanying low and high $\mathrm{Ki}-67 \mathrm{LIs}$ and histological features used for classifying astrocytic tumours is supported 


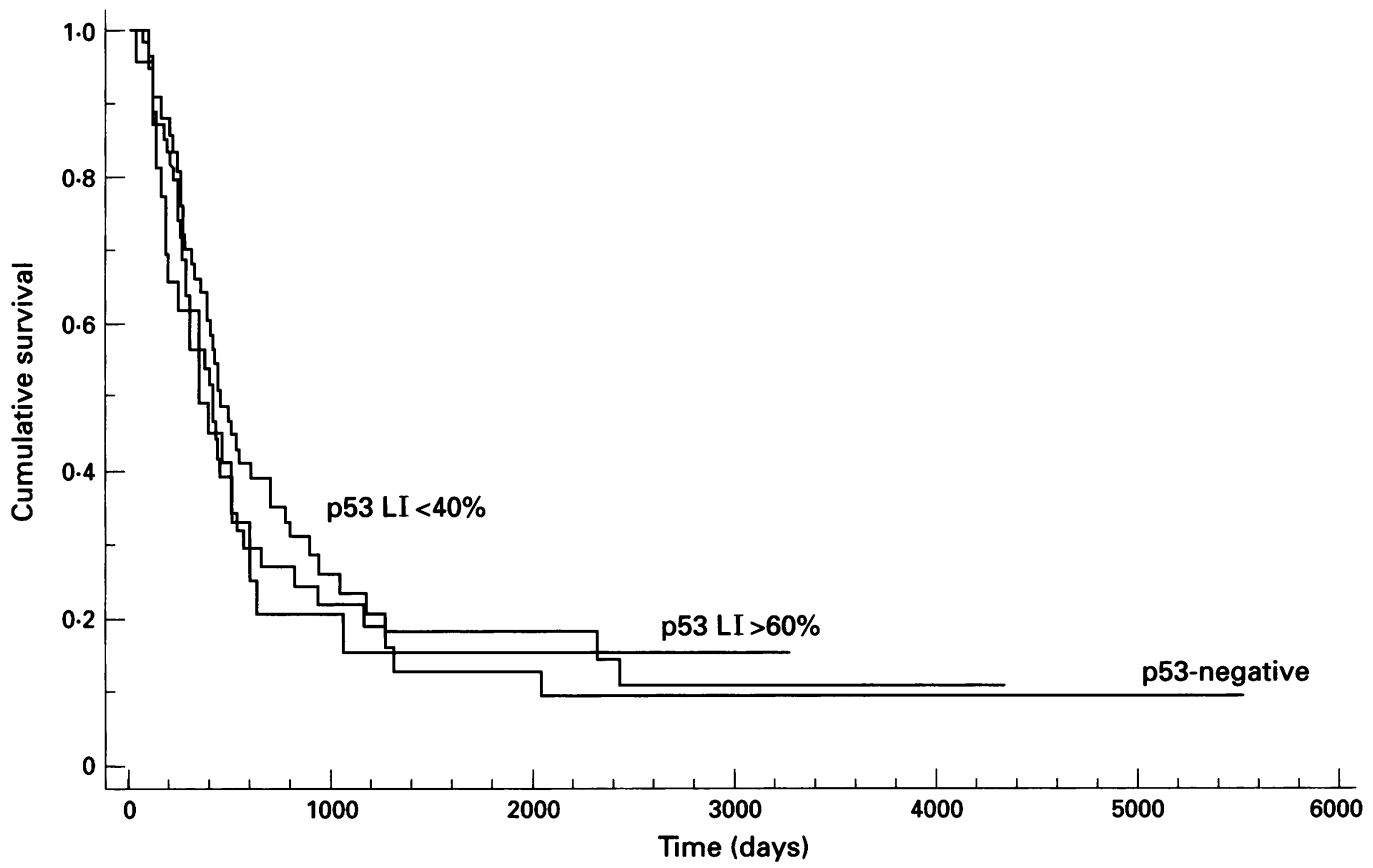

Figure 5 Survival curves for three categories of p53 immunolabelling.

by the distribution of fibrillary astrocytomas and glioblastomas across the $\mathrm{Ki}-67 \mathrm{LI}$ categories. Even though the use of $\mathrm{Ki}-67 \mathrm{LI}$ as a truly objective measure of astrocytic tumour type is precluded by the overlap of $\mathrm{Ki}-67$ LIs across the histological range, we suggest that the association between $\mathrm{Ki}-67 \mathrm{LI}$, tumour type, and prognosis makes $\mathrm{Ki}-67$ immunohistochemistry a valuable adjunct to the histological diagnosis of astrocytic tumours.

After the publication of studies that have reported a correlation between p53 immunohistochemistry and survival in patients with malignant melanomas and some carcinomas, ${ }^{14-17}$ the other principal aim of our study was to assess the value of p53 immunohistochemistry in predicting outcome in the range of cerebral astrocytic tumours. In agreement with several previous reports, ${ }^{12} 334142$ and replicating the results of our earlier study of p53 accumulation in astrocytomas, ${ }^{31}$ we have shown in this larger series of 123 cases that nuclear accumulation of the p53 protein occurs in about two thirds of anaplastic astrocytomas and glioblastomas, and that high p53 Ls are not a feature of p53 positive fibrillary astrocytomas. Despite these results, there is no relation between patterns of p53 immunolabelling and survival; either for all astrocytic tumours together, or for each type of astrocytoma alone. In the study by Jaros et $a l^{12}$ a small difference was detected between the survival curves for patients with p53 positive and p53 negative astrocytic tumours. This study differs from ours, however, because the number of patients was small, and the tumours were predominantly glioblastomas. Our results agree with those of a recent study by Chozick et $a l^{43}$ who examined the same range of astrocytic tumours and showed no independent association between p53 protein accumulation and survival.
Accumulation of the $\mathrm{p} 53$ protein can be the result of various mechanisms, and is not only a consequence of p53 mutation. ${ }^{25}{ }^{27}$ In cells with damaged DNA, levels of wild type p53 increase to immunohistochemically detectable levels as part of the reparative processes in which p53 participates by halting the cell cycle in $\mathrm{G}_{1}{ }^{44}$ Increased levels might also occur when wild type $\mathrm{p} 53$ is bound to overexpressed quantities of cellular proteins, such as MDM2. In normal cells, these two proteins regulate each other, but excess MDM-2 produced by amplification of the $m d m-2$ gene inhibits the function of wild-type p53. ${ }^{2645}$ Accumulation of $\mathrm{p} 53$ protein in the absence of p53 gene mutations occurs in a variety of tumours, and only about $50 \%$ of the astrocytomas that exhibit p53 accumulation contain a detectable p53 gene mutation to explain it. ${ }^{42}$ Overexpression of the $m d m-2$ gene is, however, rare in astrocytomas, ${ }^{2829}$ and cannot account for this discrepancy. The abnormal regulation of other, as yet undefined, proteins to which $\mathrm{p} 53$ binds may be responsible for its increased stability. Alternatively, we may just be seeing an increase in wild type p53 in response to the DNA damage that accumulates progressively across the range of astrocytomas. ${ }^{46}$

Mutation of the p53 gene or the abnormal binding of $\mathrm{p} 53$ to other proteins may inactivate the $\mathrm{p} 53$ protein. ${ }^{25}$ Studies on $\mathrm{p} 53$ deficient mice that develop normally but are prone to develop neoplasia ${ }^{47}$ have shown that, whereas p53 regulates the cycle of stressed cells, its presence is not crucial for embryogenesis. Inactivation of the $\mathrm{p} 53$ protein, however, might be responsible for replication of DNA errors that promote the mutational activation of oncogenes and a subsequent increase in cell proliferation. Two studies have looked at the relation between p53 labelling and growth fraction in astrocytomas. Haapasalo et $a l^{33}$ 
have reported that, across all grades of astrocytoma, p53 positive tumours have a higher growth fraction than p53 negative tumours, as assessed by immunolabelling with an antibody against PCNA. Jaros et al ${ }^{12}$ found that p53 positive astrocytomas of all grades had a higher $\mathrm{Ki}-67 \mathrm{LI}$ than p53-negative astrocytomas. We have found some association between the pattern of p53 expression and growth fraction as assessed by immunohistochemistry with a $\mathrm{Ki}-67$ antibody. Tumours in the p53 LI > 60\% category showed a higher median $\mathrm{Ki}-67 \mathrm{LI}$ than the other two categories, but this phenomenon was not translated into shorter survival.

In conclusion, our study has shown that conventional histological assessment of astrocytic tumours remains the best guide to prognosis. Immunohistochemistry with the $\mathrm{Ki}-67$ antibody is also of value in predicting survival, but our multivariate analysis disclosed its close relation with histological diagnosis. By contrast with tumours elsewhere, immunohistochemistry for accumulation of the $\mathrm{p} 53$ protein has no prognostic value in astrocytic tumours. This may reflect either the heterogeneity of p53 accumulation or the relative importance of other molecular genetic abnormalities involved in astrocytoma progression, such as genomic losses on chromosome $19 q{ }^{48}$

1 Kleihues P, Burger PC, Scheithauer BW. Histological typing of tumours of the central nervous system. 2nd ed. typing of tumours of the

2 Vandenberg SR. Current diagnostic concepts of astrocytic tumours. F Neuropathol Exp Neurol 1992;51:644-57.

3 Russell DS, Rubinstein LJ. Tumours of central neuroepithelial origin. In: Pathology of tumours of the nervous system. 5th ed. London: Edward Arnold, 1989:83-350.

4 Burger PC, Vogel FS, Green SB, Strike TA. Glioblastoma multiforme and anaplastic astrocytoma. Cancer 1985;56: 1106-11.

5 Ellison DW, Weller RO. Letter on the immunohistochemical assessment of proliferation rates in brain tumours. Neuropath Appl Neurobiol 1992;18:626-7.

6 Louis DN, Edgerton S, Thor AD, Hedley-Whyte ET. Proliferating cell nuclear antigen and $\mathrm{Ki}-67$ immunohistochemistry in brain tumours: a comparative study. Acta Neuropathol (Berl) 1991;81:675-9.

7 Morimura T, Kitz K, Budka H. In situ analysis of cell kinetics in human brain tumours. Acta Neuropathol kinetics in human brain

8 Raghavan R, Steart PV, Weller RO. Cell proliferation in the diagnosis of astrocytomas, anaplastic astrocytomas, and glioblastoma multiforme: a Ki-67 study. Neuropathol Appl Neurobiol 1990;16:123-33.

9 Gerdes J, Li L, Schlueter C, et al. Immunobiochemical and molecular biologic characterization of the cell proliferation-associated nuclear antigen that is defined by monoclonal antibody Ki-67. Am f Pathol 1991;138: 867-73.

10 Brown DC, Gatter KC. Monoclonal antibody Ki-67: its use in histopathology. Histopathology 1990;17:489-503.

11 Cattoretti G, Becker MH, Key G, et al. Monoclonal antibodies against recombinant parts of the $\mathrm{Ki}-67$ antigen
(MIB-1 and MIB-3) detect proliferating cells in microwave-processed formalin-fixed paraffin sections. microwave-processed format

12 Jaros E, Perry RH, Adam L, et al. Prognostic implications of p53 protein, epidermal growth factor receptor, and $\mathrm{Ki}-$ 67 labelling in brain tumours. $B r F$ Cancer 1992;66: 373-85.

13 Zuber P, Hamou M-F, de Tribolet N. Identification of proliferating cells in human gliomas using the monoclonal antibody Ki-67. Neurosurgery 1988;22:364-8.

14 Barnes DM, Dublin EA, Fisher CJ, Levison DA, Millis RR. Immunohistochemical detection of p53 protein in mammary carcinoma: an important new independent indicator of prognosis? Hum Pathol 1993;24:469-76.

15 McGregor JM, Yu CC, Dublin EA, Barnes DM, Levison DA, MacDonald DM. p53 immunoreactivity in human malignant melanoma and dysplastic naevi. $\mathrm{Br} \mathcal{f}$ Dermatol 1993;128:606-11.

16 Quinlan DC, Davidson AG, Summers CL, Warden HE, Doshi HM. Accumulation of p53 protein correlates with a poor prognosis in human lung cancer. Cancer Res 1992;52:4828-31.

17 Thomas DJ, Robinson M, King P, et al. p53 expression and clinical outcome in prostate cancer. Br $\mathcal{F}$ Urol 1993; 72:778-81.

18 Fields S, Jang SK. Presence of a potent transcription activating sequence in the p53 protein. Science 1990;249. 1046-9.

19 Lane DP. The regulation of $p 53$ function: Steiner award lecture. Int $\mathcal{f}$ Cancer 1994;57:623-7.

20 Marx J. How p53 suppresses cell growth. Science 1993; 262:1644-5.

21 Prives $C$. Doing the right thing: feedback control and p53. Curr Opin in Cell Biol 1993;5:214-8.

22 Clarke AR, Purdie CA, Harrison DJ, et al. Thymocyte apoptosis induced by $\mathrm{p} 53$-dependent and independent pathways. Nature 1993;362:849-52.

23 Vile RG. p53: a gene for all tumours. BMF 1993;307: 1226-7.

24 Kern SE, Pietenpol JA, Thiagalingam S, Seymour A Kinzler KW, Vogelstein B. Oncogenic forms of p53 inhibit p53-regulated gene expression. Science 1992;256: 827-30.

25 Vogelstein B, Kinzler KW. p53 function and dysfunction Cell 1992;70:523-6.

26 Wu X, Bayle JH, Olson D, Levine AJ. The p53-mdm-2 autoregulatory feedback loop. Genes Dev 1993;7 1126-32.

27 Louis DN. The p53 gene and protein in human brain tumours. F Neuropathol Exp Neurol 1994;53:11-21

28 Reifenberger G, Liu L, Ichimura K, Schmidt EE, Collins VP. Amplification and overexpression of the $\mathrm{mdm}-2$ gene in a subset of human malignant gliomas without gene in a subset of human malignant gliom

29 Rubio MP, von Deimling A, Yandell DW, Wiestler OD Gusella JF, Louis DN. Accumulation of wild type p53 protein in human astrocytomas. Cancer Res 1993;53: protein

30 Hall PA, Lane DP. p53 in tumour pathology: can we trust immunohistochemistry?-revisited! $\mathcal{f}$ Pathol 1994;172 $1-4$.

31 Ellison DW, Gatter KC, Steart PV, Lane DP, Weller RO Expression of the p53 protein in a spectrum of astrocytic tumours. F Pathol 1992;168:383-6.

32 Barbareschi M, Iuzzolino P, Pennella A, et al. p53 protein expression in central nervous system neoplasms. F Clin Pathol 1992;45:583-6.

33 Haapasalo H, Isola J, Sallinen P, Kalimo H, Helin H, Rantala I. Aberrant p53 expression in astrocytic neoplasms of the brain: association with proliferation. $A m^{\mathcal{J}}$ pathol 1993;142:1347-51.

34 EORTC Brain Tumour Group. Evaluation of CCNU, VM-26 plus CCNU, and procarbazine in supratentorial brain tumours. $\mathcal{F}$ Neurosurg 1981;55:27-31.

35 EORTC Brain Tumour Group. Misonidazole in radiotherapy of supratentorial malignant brain gliomas in adult patients: a randomised double-blind study European fournal of Cancer and Clinical Oncology 1983; 19:39-42.

36 Stata Corporation. Stata reference manual: release 3.1. 6th ed. College Station, TX: Stata Corporation, 1993.

37 Burger PC, Green SB. Patient age, histologic features, and length of survival in patients with glioblastoma multiforme. Cancer 1987;59:1617-25.

38 Cohadon F, Aouad N, Rougier A, Vital C, Rivel J, Dartigues JF. Histologic and non-histologic factors correlated with survival time in supratentorial astrocytic related with survival time in suprat

$39 \mathrm{Kim}$ TS, Halliday AL, Hedley-Whyte ET, Convery K Correlates of survival and the Daumas-Duport grading system for astrocytomas. $\mathcal{F}$ Neurosurg 1991;74:27-37.

40 Onda K, Davis RL, Wilson CB, Hoshino T. Regiona differences in bromodeoxyuridine uptake, expression of $\mathrm{Ki}-67$ protein and nucleolar organizer region counts in glioblastoma multiforme. Acta Neuropathol (Berl) 1994; 87:586-93.

41 Karamitopoulou E, Perentes E, Diamantis I. p53 protein expression in central nervous system tumours: an immunohistochemical study with CM1 polyvalent and DO-7 monoclonal antibodies. Acta Neuropathol (Berl) 1993;85:611-6.

42 Louis DN, von Deimling A, Chung RY, et al. Comparative study of p53 gene and protein alterations in human astrocytic tumors. $f$ Neuropathol Exp Neurol 1993;52: astrocy.

43 Chozick BS, Pezzullo JC, Epstein MH, Finch PW. Prognostic implications of p53 overexpression in supratentorial astrocytic tumours. Neurosurgery 1994;35: 831-8.

44 Lane DP. Cancer. p53, guardian of the genome. Nature 1992;358:15-6.

45 Momand J, Zambetti GP, Olson DC, George D, Levine AJ. The $m d m-2$ oncogene product forms a complex with the $\mathrm{p} 53$ protein and inhibits $\mathrm{p} 53$-mediated transactivation. Cell 1992;69:1237-45.

46 von Deimling A, von Ammon K, Schoenfeld D, Wiestler OD, Seizinger BR, Louis DN. Subsets of glioblastoma multiforme defined by molecular genetic analysis. Brain Pathol 1993;3:19-26.

47 Donehower LA, Harvey M, Slagle BL, et al. Mice deficient for p53 are developmentally normal but susceptible to spontaneous tumours. Nature 1992;356:215-21.

48 von Deimling $A$, Bender B, Jahnke $R$, et al. Loci associated with malignant progression in astrocytomas: A candidate on chromosome 19q. Cancer Res 1994;54:1397-401. 